\title{
Marginal effects of glucose, insulin and insulin-like growth factor on chemotherapy response in endothelial and colorectal cancer cells
}

\author{
EKATERINA VOLKOVA ${ }^{1}$, BRIDGET A. ROBINSON ${ }^{1,2}$, JINNY WILLIS $^{3}$, \\ MARGARET J. CURRIE ${ }^{1}$ and GABI U. DACHS ${ }^{1}$ \\ ${ }^{1}$ Mackenzie Cancer Research Group, Department of Pathology, University of Otago Christchurch; \\ ${ }^{2}$ Canterbury Regional Cancer and Blood Service, Canterbury District Health Board; \\ ${ }^{3}$ Lipid and Diabetes Research Group, Christchurch Hospital, Christchurch 8140, New Zealand
}

Received April 10, 2013; Accepted October 24, 2013

DOI: $10.3892 / \mathrm{ol} .2013 .1710$

\begin{abstract}
Resistance to chemotherapy is a major clinical issue for patients with colorectal cancer. Obesity has been associated with a poorer outcome and is a possible mechanism of resistance. The aim of the present study was to investigate the effect of obesity-related factors on the cell response to standard chemotherapy in stromal and colorectal cancer cells. Viability was measured following the treatment of colorectal cancer cell lines (WiDr and SW620) and stromal cells (human microvascular endothelial cells) in vitro with 5-fluorouracil, irinotecan and oxaliplatin under obesity-related conditions [elevated levels of insulin, insulin-like growth factor-1 (IGF-1) and glucose] and compared with non-elevated conditions. Obesity-related conditions alone increased cell viability and in selected cases, accumulation of the transcription factor, hypoxia-inducible factor-1. However, these conditions did not consistently increase resistance to the chemotherapy agents tested. The combination of IGF-1 and extremely low-dose chemotherapy significantly induced cell viability in WiDr colorectal cancer cells. These in vitro results may have clinical importance in an environment of increasing rates of obesity and colorectal cancer, and the frequent under-dosing of obese cancer patients.
\end{abstract}

\section{Introduction}

Resistance to chemotherapeutic agents, either de novo or developing during a course of treatment, is a major clinical issue for patients with colorectal cancer (1-3). Current response

Correspondence to: Dr Gabi Dachs, Mackenzie Cancer Research Group, Department of Pathology, University of Otago Christchurch, PO Box 4345, 2 Riccarton Ave, Christchurch 8140, New Zealand E-mail: gabi.dachs@otago.ac.nz

Key words: proliferation, stroma, low dose, fluorouracil, irinotecan, oxaliplatin rates to combination chemotherapy are $\sim 50 \%$, and as resistance develops in almost all patients, understanding the mechanisms behind this is vital. Despite previous intense investigations, these mechanisms are not completely understood.

For disease stages II and above, chemotherapy is routine, consisting of intravenous 5-fluorouracil (5-FU; or oral capecitabine) with or without oxaliplatin and/ or irinotecan (4). 5-FU is an analogue of uracil, which is metabolised intracellularly to toxic compounds, causing DNA damage and the blocking of DNA replication and translation (5). Oxaliplatin is a platinum-based drug, which forms platinum-DNA adducts in cells, causing $\mathrm{G}_{2}$ arrest, inhibiting growth and leading to apoptosis (6). Irinotecan, once converted to the active metabolite SN-38, binds to and inhibits topoisomerase I at the initial stages of DNA replication, which leads to cell cycle arrest and DNA damage with subsequent apoptosis (7).

Obesity is an established risk factor for colorectal cancer incidence and mortality (8-10), but the impact on survival and treatment response remains controversial (11-14). In breast cancer patients, the response rate to neoadjuvant chemotherapy (predominantly anthracycline-based regimes) has been lower in overweight and obese patients compared with normal and underweight patients (15). Obesity is associated with insulin resistance, which alters the levels of plasma glucose, insulin and insulin-like growth factor-1 (IGF-1) (16-18).

Insulin is a potent mitogen and stimulates DNA synthesis (19). Experimental models have shown that pretreatment with insulin increases the effect of subsequent 5-FU treatment in the human colon cancer cell line, Ls-174-t (5). Insulin also increases 5-FU uptake and 5-FU-mediated apoptosis. By contrast, insulin has been found to decrease the toxic effects of 5-FU in HT29 colorectal cancer cells (20).

IGF-1 functions as an anti-apoptotic growth factor (21). Breast cancer cells with abnormalities in the IGF-pathway showed IGF-1-mediated suppression of apoptosis and subsequently, were more resistant to doxorubicin and paclitaxel (22). Similarly, IGF-1 increased resistance to 5-FU in the SW480 colon cancer cell line, which was reversible by IGF-1 receptor (IGF-1R) inhibition (23). In addition, HT29 colorectal cancer 
cells, selected for resistance to 5-FU and oxaliplatin, showed increased expression and activation of IGF-1R (3).

Hypoxic conditions promote the development of treatment resistance, partly through hypoxia-inducible factor-1 (HIF-1)-mediated pathways (24). HIF-1 is the master regulator of molecular responses to hypoxia, controlling $>100$ genes involved in tumour aggression (25). Previous studies have shown that HIF-1 $\alpha$ expression, stability and activity may be modulated by metabolic disturbances, including a number of cytokines and growth factors and specifically, insulin and IGF-1 $(26,27)$.

Conflicting results with regard to the impact of obesity-related factors on chemoresponse have been published previously $(5,20,23)$, as aforementioned. The aim of the current study was to investigate the effect of increased levels of insulin and IGF-1 and altered levels of glucose, on the cellular response to standard chemotherapy in vitro. The response of two colorectal cancer cells, one derived from a primary adenocarcinoma (WiDr), the other from a metastatic site of an adenocarcinoma (SW620), was compared with a stromal cell type [human microvascular endothelial cells (HMEC)-1)]. The duration of stimulation (pretreatment time) was also investigated to distinguish between acute and chronic disturbance in the insulin/IGF-1 axis.

\section{Materials and methods}

Cell culture. Human colon cancer cells (primary adenocarcinoma, WiDr and metastatic adenocarcinoma, SW620; American Type Culture Collection, Manassas, VA, USA) and HMEC-1 cells (Centers for Disease Control and Prevention, Atlanta, GA, USA) were used (28). Cancer cell genotypes are listed in Table I and HMEC-1 cells were assumed to be wild-type (no contrasting evidence was reported). Cells were cultivated in high $(25 \mathrm{mM})$ or normal $(5.6 \mathrm{mM})$ glucose Dulbecco's modified Eagle's medium (DMEM; Gibco, Carlsbad, CA, USA) with $10 \%$ cosmic calf serum (CCS; Thermo Scientific HyClone, Logan, UT, USA) in standard conditions (humidified at $37^{\circ} \mathrm{C}$ in $5 \% \mathrm{CO}_{2}$ ), unless specified otherwise. Glucose concentrations in cell culture were monitored over time (Optium Xceed; Abbott Diabetes Care, Doncaster, Australia), demonstrating that glucose concentrations reduced by $\sim 18 \%$ over $24 \mathrm{~h}$ in a confluent cell culture.

Cell viability assay. Cells were cultivated in DMEM with $10 \%$ CCS with high $(25 \mathrm{mM})$ or normal $(5.6 \mathrm{mM})$ glucose concentrations and incubated for $24 \mathrm{~h}$. Plain media, IGF-1 (13 nM; Sigma-Aldrich, St. Louis, MO, USA) or insulin (10 nM; Invitrogen Life Technologies, Carlsbad, CA, USA) were added to the cells 24,4 or $0 \mathrm{~h}$ prior to the addition of 5-FU $(0.2-200 \mu \mathrm{M})$, oxaliplatin $(0.001-100 \mu \mathrm{M})$ or irinotecan $(0.001-100 \mu \mathrm{M})$. Each treatment was tested in four wells per experiment, with three independent experiments, and the cells were treated for $72 \mathrm{~h}$. Cell viability was estimated by standard 3-(4,5-dimethylthiazol-2-yl)-2,5-diphenyltetrazolium bromide (MTT) assay (29), calculated as a percentage of the controls ( $0 \mu \mathrm{M}$ of chemotherapy drug) and adjusted for background absorbance. The concentration of drug able to reduce viability to $50 \%\left(\mathrm{IC}_{50}\right)$ was calculated from equations obtained by model fitting. Although it is accepted that MTT, an indicator of meta- bolically active mitochondria, potentially overestimates the number of viable cells compared with several other viability methods (30), it remains widely used in drug discovery and allows for comparisons with previously published data.

Western blot analysis. Media was replaced with serum-reduced DMEM $(0.1 \%$ CCS $) 24 \mathrm{~h}$ prior to and throughout the experiment. The cells were treated for $4 \mathrm{~h}$ with IGF-1 $(13 \mathrm{nM})$, insulin (10 $\mathrm{nM}), \mathrm{CoCl}_{2}$ (100 $\mu \mathrm{M}$ positive control) (31) or plain media (negative control). Nuclear protein fractions were extracted and analysed by western blot analysis following standard protocols (31). A total of $40 \mu \mathrm{g}$ protein extract was loaded per well for the total and nuclear fractions. Anti-HIF-1 $\alpha$ (1:250; clone 54/HIF-1 $\alpha$; BD Biosciences, San Jose, CA, USA) and anti- $\beta$-actin (1:2,000; clone AC-15; Sigma-Aldrich) were simultaneously used as primary antibodies to detect HIF-1 $\alpha$ and to verify equal loading of protein. Horseradish peroxidase (HRP)-conjugated polyclonal goat anti-mouse antibody (1:1,000; DakoCytomation, Glostrup, Denmark) was used as a secondary antibody. For IGF-1R protein detection, total protein extracts were analysed, using anti-human IGF-1R (1:100; C-20; Santa Cruz Biotechnology, Inc., Santa Cruz, CA, USA) as the primary antibody and HRP-conjugated polyclonal goat anti-rabbit antibody (1:1,000; DakoCytomation) as the secondary antibody.

HIF-1 $\alpha$ cell-based enzyme-linked immunosorbent assay. Cells were plated into 96 -well plates provided in the human/mouse total HIF-1 $\alpha$ immunoassay kit (R\&D Systems, Minneapolis, MN, USA) at recommended concentrations $\left(10^{4} /\right.$ well) and cultivated under standard conditions. The media was replaced with serum-reduced DMEM (0.1\% CCS) $24 \mathrm{~h}$ prior to and throughout the experiments. The cells were treated with $\mathrm{CoCl}_{2}$ (100 $\mu \mathrm{M}$ positive control), plain media (negative control), IGF-1 (13 nM) and insulin (10 $\mathrm{nM})$ for $4 \mathrm{~h}$. The cells were then fixed with $4 \%$ formaldehyde and analysed immediately by immunoassay according to the manufacturer's instructions.

Data analysis. SPSS 16.0 (SPSS, Inc., Chicago, IL, USA) and Microsoft Excel 2007 (Microsoft Corporation, Redmond, WA, USA) software were used for the statistical analysis and graphical presentation of the results.

For the MTT assay results, several linear regression models using $\ln$ transformation of drug concentration $(\mu \mathrm{M})$ or cell viability (percent) or the two variables together were tested. The model was considered to be a good fit if the $\mathrm{R}^{2}$ value was $>0.8$. Different models were allowed to be used for the various cell lines and chemotherapy drugs. However, within these, the same model was used across the various growth factors, pretreatments and media conditions. Selected models were used to calculate the $\mathrm{IC}_{50}$ and ultra-low dose (ULD) values and for multiple regression analysis.

The following linear regression models were selected to fit the viability data according to the $\mathrm{R}^{2}$ values: $\ln$ transformation of drug concentration for WiDr treated with 5-FU and oxaliplatin, for all treatments of SW620 and for HMEC-1 treated with 5-FU; and $\ln$ transformation of cell viability for WiDr treated with irinotecan and for HMEC-1 treated with oxaliplatin and irinotecan. $\mathrm{IC}_{50}$ values were calculated from the equations obtained by model fitting. These values were 
Table I. Cellular characteristics and viability of cancer and stromal cells grown in high or normal glucose media, following 5-day treatment with insulin or IGF-1 compared with controls with no pretreatment (equivalent to 100\%).

\begin{tabular}{|c|c|c|c|c|c|}
\hline & \multirow[b]{2}{*}{ Mutated oncogenes $^{\mathrm{a}}$} & \multicolumn{2}{|c|}{ High glucose (25 mM) } & \multicolumn{2}{|c|}{ Normal glucose (5.6 mM) } \\
\hline & & Insulin (10 nM) & IGF-1 (13 nM) & Insulin $(10 \mathrm{nM})$ & IGF-1 (13 nM) \\
\hline $\mathrm{WiDr}^{\mathrm{b}}$ & TP53, PIK3CA and BRAF & $142 \pm 11$ & $155 \pm 12$ & $114 \pm 21$ & $115 \pm 10$ \\
\hline SW620 & TP53 and KRAS & $124 \pm 4$ & $136 \pm 7$ & $113 \pm 10$ & $137 \pm 1$ \\
\hline HMEC- $1^{\text {d }}$ & & $113 \pm 3$ & $136 \pm 8$ & $116 \pm 1$ & $125 \pm 4$ \\
\hline
\end{tabular}

${ }^{\mathrm{a}}(53,54)$; ${ }^{\mathrm{b}}$ primary and ${ }^{\mathrm{c}}$ metastatic colorectal adenocarcinomas; ${ }^{\mathrm{d}}$ dermal microvascular endothelial cells. $\mathrm{n}=9$; data are presented as the mean \pm SD, according to viability assay. IGF-1, insulin-like growth factor-1; HMEC-1, human microvascular endothelial cells.

A

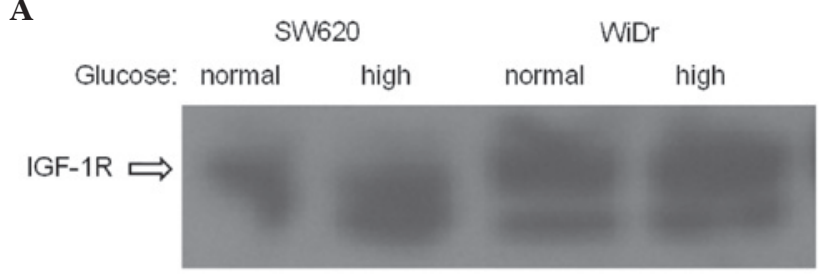

\section{B}

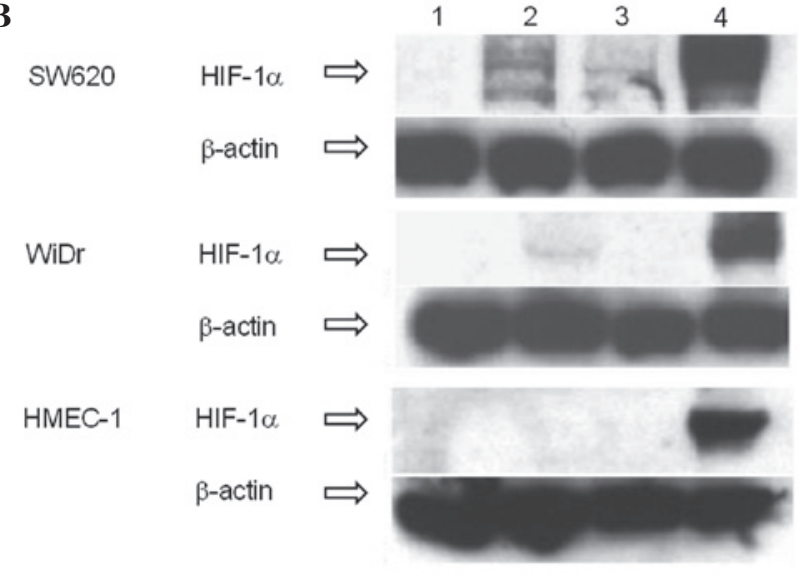

C

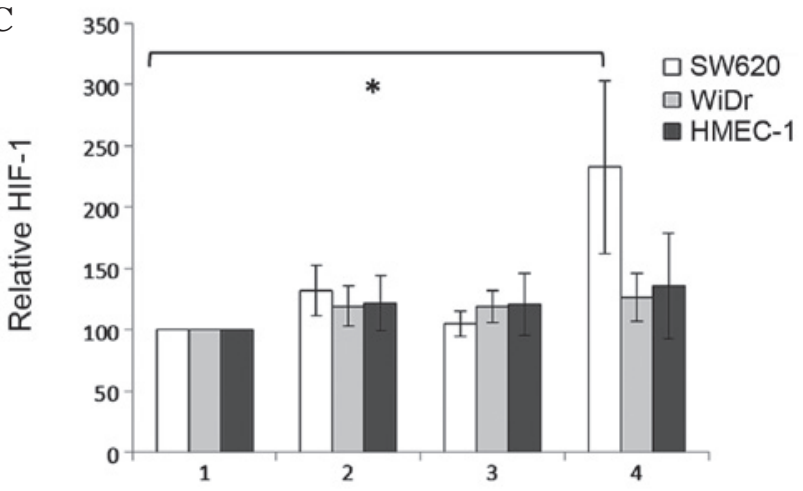

Figure 1. (A) Protein levels of IGF-1R in WiDr and SW620 cells, as detected by western blot analysis. (B) Western blot analysis of HIF-1 $\alpha$ protein levels in nuclear fractions of colon cancer cell lines (WiDr and SW620) and human microvascular endothelial cells (HMEC-1) in response to IGF-1 $(13 \mathrm{nM})$, insulin $(10 \mathrm{nM})$ or $\mathrm{CoCl}_{2}(100 \mu \mathrm{M})$. Protein loading, $40 \mu \mathrm{g} / \mathrm{well}$; HIF-1 $\alpha$ band detected at $\sim 120 \mathrm{kDa}$. Lane 1, untreated (negative control); 2, IGF-1; 3, insulin; and 4, $\mathrm{CoCl}_{2}$ (positive control). (C) Cell-based ELISA of HIF-1 $\alpha$ protein levels in total protein fraction in response to IGF-1 and insulin. Column 1, untreated (negative control); 2, IGF-1; 3, insulin; and 4, $\mathrm{CoCl}_{2}$ (positive control). HIF-1 $\alpha$ levels were standardized to untreated cells $(100 \%)$. $* \mathrm{P}=0.031$. IGF-1R, insulin-like growth factor-1 receptor; HIF-1 $\alpha$, hypoxia-inducible factor-1 $\alpha$; ELISA, enzyme-linked immunosorbent assay; HMEC-1, human microvascular endothelial cells. used to compare the effect of growth factors on the cellular response to chemotherapy. Independent sample t-tests were used to compare $\mathrm{IC}_{50}$, ULD and HIF-1 $\alpha$ protein levels between the various treatments. In the multivariable regression analysis the effect of growth factors on the response to chemotherapy drugs was estimated by B coefficients (regression 'slopes').

\section{Results}

Effect of growth factors and glucose concentrations on cell viability. Glucose concentrations were specifically selected to be clinically relevant and are those used widely in cancer cell culture studies. The lower glucose concentration $(5.6 \mathrm{mM})$ approximates the lower threshold for normal fasting glucose and the high glucose concentration $(25 \mathrm{mM})$ falls in the hyperglycemic range associated with diabetes (32). Specifically, high glucose concentrations are standard in cancer cell culture studies (33). Growth factor concentrations were selected from previously published patient data; $10 \mathrm{nM}$ insulin (plasma, $2 \mathrm{nM}$ ) (34) and $13 \mathrm{nM}$ IGF-1 (plasma, $109 \mathrm{ng} / \mathrm{ml}$ ) (35).

IGF-1 and insulin increased the proportion of cells with metabolically active mitochondria (cell viability) of stromal and cancer cells by between 13 and 55\% (HMEC-1 in high glucose with insulin and WiDr in high glucose with IGF-1, respectively). IGF-1 generally increased viability more than insulin (with the exception of WiDr under normal glucose conditions), and an increased viability was more apparent in high glucose than in normal glucose conditions (with the exception of SW620 with IGF-1 and HMEC-1 with insulin) (Table I).

Western blot analysis confirmed that the two cancer cell lines expressed IGF-1R (36), with levels not notably affected by glucose concentration (Fig. 1A). IGF-1R levels appeared higher in WiDr compared with SW620, as reported previously (36).

Effect of IGF-1, insulin and glucose concentrations on cellular response to chemotherapy. The concentrations of chemotherapy agents used in the current study were within the clinically relevant ranges: 5-FU, $0.2-200 \mu \mathrm{M}$ (maximum plasma concentration, $426 \mu \mathrm{M}$ ); oxaliplatin, 0.001-100 $\mu \mathrm{M}$ (maximum plasma concentration, $3.3 \mathrm{mM}$ ); and irinotecan, $0.001-100 \mu \mathrm{M}$ (maximum plasma concentration, $10 \mathrm{mM}$ ) (37-42).

The mean $\mathrm{IC}_{50}$ and results of the t-tests for each condition in all cell lines are presented in Table II. For the majority 


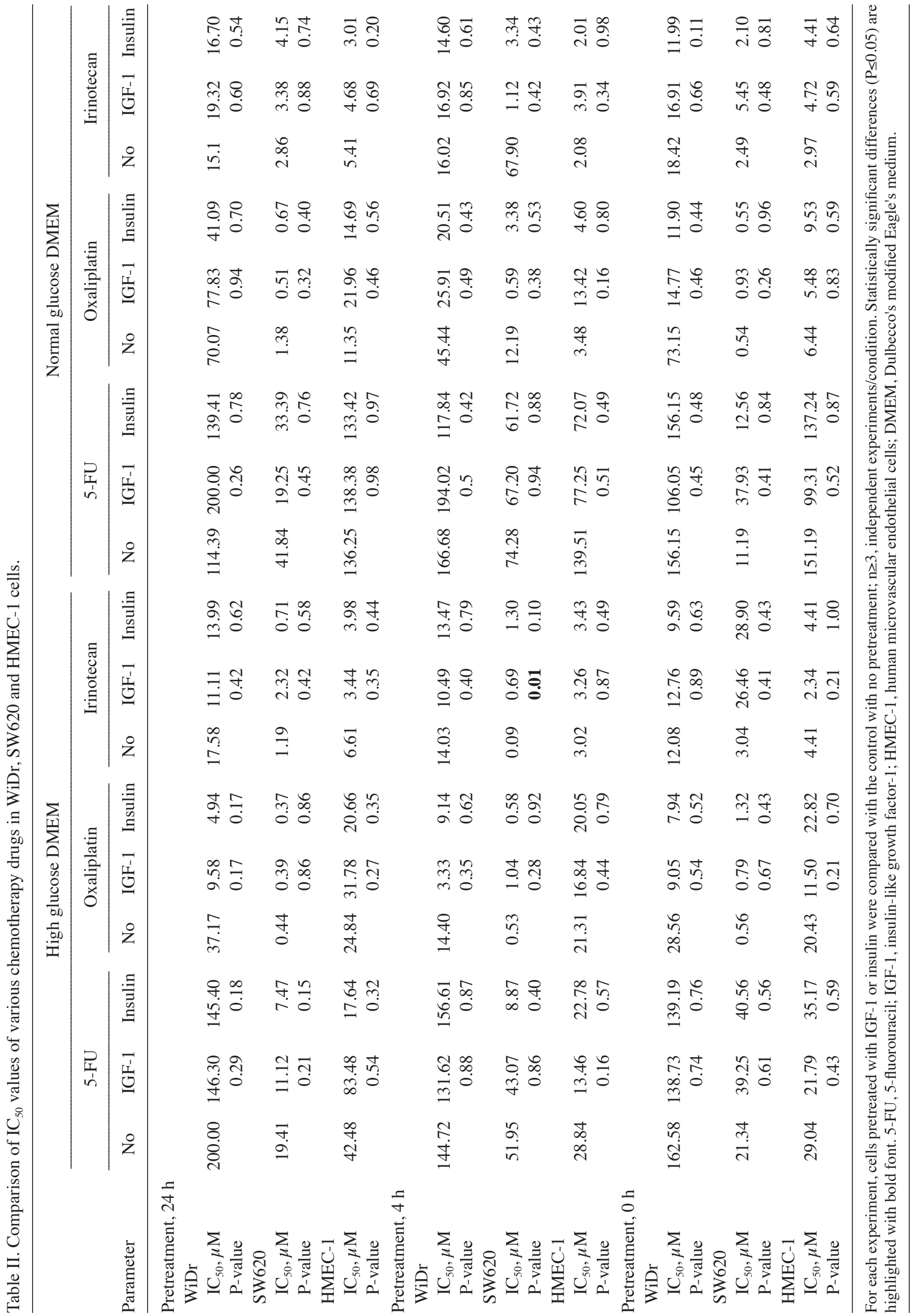


of cell lines, no significant difference was identified in the concentrations of drugs required to reduce $\mathrm{IC}_{50}$ between the growth factor-treated and control cells. The duration of incubation with growth factors did not consistently modify the drug response, nor did the glucose concentration. Only one set of data demonstrated significant differences; IGF-1-treated SW620 cells in high glucose were more resistant to irinotecan treatment compared with the controls $(\mathrm{P}=0.009)$. Treatment with irinotecan in the presence of insulin under the same conditions showed a similar trend, although a significant difference was not observed $(\mathrm{P}=0.096)$.

To compare entire response curves, as opposed to single data points $\left(\mathrm{IC}_{50}\right)$, a multivariable regression model was developed (Table III). As predicted, chemotherapy drug concentration exhibited a significant effect on cell viability in all cases $(\mathrm{P}<0.001)$. In the majority of cases, the presence or the duration of pretreatment with growth factors, or the glucose concentration of the media did not significantly change the chemoresponse.

Of the results that showed statistically significant changes, the addition of IGF-1 to tumour cell lines increased the resistance to chemotherapy: WiDr 5-FU in normal glucose at $24 \mathrm{~h}(\mathrm{P}<0.001)$ and $4 \mathrm{~h}(\mathrm{P}<0.001)$; WiDr oxaliplatin in normal glucose at $24 \mathrm{~h}(\mathrm{P}<0.001)$ and $4 \mathrm{~h}(\mathrm{P}<0.001)$; SW620 5-FU in normal glucose at $0 \mathrm{~h}(\mathrm{P}=0.007)$; and $\mathrm{SW620}$ irinotecan in high glucose at $4 \mathrm{~h}(\mathrm{P}=0.015)$.

The addition of insulin to WiDr significantly increased sensitivity to chemotherapy: 5-FU in high glucose at $24 \mathrm{~h}$ $(\mathrm{P}<0.001)$ and in normal glucose at $0 \mathrm{~h}(\mathrm{P}=0.006)$; and oxaliplatin in high glucose at $24 \mathrm{~h}(\mathrm{P}=0.021)$ and in normal glucose at $0 \mathrm{~h}(\mathrm{P}=0.015)$. In addition, insulin induced variable effects in the SW620 cells, such as increased sensitivity; $5-\mathrm{FU}$ in high glucose at $24 \mathrm{~h}(\mathrm{P}=0.004)$ and $4 \mathrm{~h}(\mathrm{P}=0.042)$, and increased resistance; oxaliplatin in high glucose at $0 \mathrm{~h}$ $(\mathrm{P}=0.034)$ and irinotecan in high glucose at $4 \mathrm{~h}(\mathrm{P}=0.011)$ and $0 \mathrm{~h}(\mathrm{P}=0.016)$.

The impact of growth factors in the HMEC-1 endothelial cell line on the chemoresponse was variable; IGF-1 in high glucose marginally increased resistance (oxaliplatin at $24 \mathrm{~h}, \mathrm{P}=0.043)$, but also sensitivity $(5-\mathrm{FU}$ at $4 \mathrm{~h}, \mathrm{P}=0.008$; oxaliplatin at $0 \mathrm{~h}, \mathrm{P}=0.011$; and irinotecan at $0 \mathrm{~h}, \mathrm{P}=0.008$ ). In normal glucose IGF-1 increased 5-FU sensitivity $(0 \mathrm{~h}$, $\mathrm{P}=0.021$ ), but marginally decreased sensitivity to oxaliplatin ( $24 \mathrm{~h}, \mathrm{P}=0.038)$. Insulin increased sensitivity (5-FU in high glucose at $24 \mathrm{~h}, \mathrm{P}=0.01$; and in normal glucose at $4 \mathrm{~h}$, $\mathrm{P}=0.016$ ), but also resistance slightly (oxaliplatin in normal glucose at $0 \mathrm{~h}, \mathrm{P}=0.032$ ).

Effect of ULDs of chemotherapy on cell viability. WiDr cells showed significantly increased viability when treated with ULDs (defined as 1/1,000 of $\mathrm{IC}_{50}$ ) of chemotherapy in normal glucose conditions with IGF-1, ranging between $182 \%$ (oxaliplatin at $4 \mathrm{~h}, \mathrm{P}=0.003)$ and $240 \%(5-\mathrm{FU}$ at $4 \mathrm{~h}, \mathrm{P}=0.018)$, compared with WiDr in normal glucose without growth factors or chemotherapy (viability, 100\%) (Table IV). Similar trends were observed at $24 \mathrm{~h}$; WiDr viability in normal glucose with IGF-1 increased to $195 \%$ with ULDs of oxaliplatin $(\mathrm{P}=0.082)$ and to $283 \%$ with ULDs of 5-FU $(\mathrm{P}=0.088)$. The viability of cells at ULDs was calculated from the equations obtained by model fitting, and the values were used to compare the effect of growth factors on the cellular response to chemotherapy.
No significant differences were identified in ULD response between growth factor-treated and control cells under high glucose conditions or insulin, and this effect was not observed in the SW620 or HMEC-1 cells.

Effect of IGF-1 and insulin on HIF-1 $\alpha$ protein levels. Western blot analysis of the nuclear protein fractions of SW620, WiDr and HMEC-1 showed extremely low or undetectable basal levels of HIF-1 $\alpha$ protein (Fig. 1B). As predicted, a marked increase in HIF-1 $\alpha$ protein was observed in all cell lines in response to $\mathrm{CoCl}_{2}$, an agent used as a positive control as it interferes with HIF-1 degradation (31). An increase in HIF-1 $\alpha$ protein levels in response to IGF-1 and insulin treatment was observed in the SW620 cells, with a weaker increase due to IGF-1 and no increase due to insulin in the WiDr cells. No visible changes from the basal HIF-1 $\alpha$ protein levels in response to IGF-1 or insulin were observed in HMEC-1.

The effect of IGF-1 and insulin on total HIF-1 $\alpha$ protein levels was further quantified using a cell-based immunoassay, with basal levels defined as $100 \%$ (Fig. 1C). An increase in HIF-1 $\alpha$ protein levels was observed in all 3 cell lines in response to $\mathrm{CoCl}_{2}$ [SW620, 233\% ( $\left.\mathrm{P}=0.031\right)$; WiDr, 126\%; and HMEC-1, 136\%]. HIF-1 $\alpha$ protein levels appeared to be increased in response to IGF-1 in SW620 (132\%; P=0.057) and to insulin and IGF-1 in WiDr (insulin, 119\%; and IGF-1, 119\%) and HMEC-1 (insulin, 121\%; and IGF-1, 121\%) cell lines, but the increases were not statistically significant.

\section{Discussion}

The present study demonstrated that the obesity-related conditions of elevated glucose, insulin and IGF-1 levels may increase cell viability and in selected cases, resistance to chemotherapy and accumulation of the global transcription factor, HIF-1. The effect became clearer when the total survival pattern of the cells was analysed in a multivariable regression model, instead of analysing single points $\left(\mathrm{IC}_{50}\right)$. Notably, however, a specific induction of cell viability by the combination of obesity-related factors and ULD chemotherapy $(0.2 \mu \mathrm{M} 5-\mathrm{FU}$ and $0.04 \mu \mathrm{M}$ oxaliplatin) was identified. This observation deserves further investigation, since the plasma levels of 5-FU in patients with colorectal cancer stay at $0.01-1 \mu \mathrm{M}$ for several days following bolus administration (37). Similarly, platinum concentrations stay at $>3 \mu \mathrm{M}(1 / 1,000$ of its maximum plasma concentration) for over $500 \mathrm{~h}$ following oxaliplatin infusion (38). In addition, extremely low doses of chemotherapy are more likely to circulate in obese cancer patients where under-dosing or capped dosing is common (43). The under-dosing of obese colorectal cancer patients has been shown to result in reduced progression-free and overall survival rates (44).

In WiDr, a significant effect of growth factors was observed more often in normal glucose conditions. By contrast, significant effects in SW620 were mainly observed in high glucose conditions, whereas in HMEC-1, the results did not differ according to glucose concentration. These results indicate that different types of colorectal cancer and stromal cells may vary in their dependence on glucose levels and the insulin/IGF axis, particularly when treated with chemotherapy. This may be associated with the particular metabolic pathways each cancer 


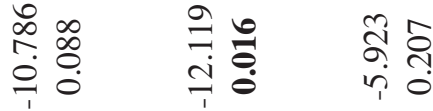

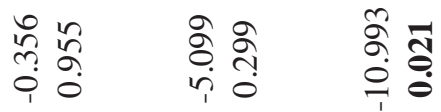

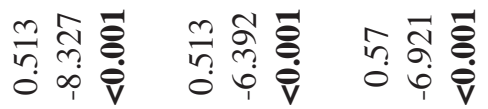

華

in

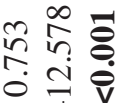

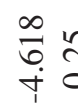

$\begin{array}{ll}\vec{\infty} & \infty \\ \infty & 0 \\ 0 & 0 \\ 0 & 0\end{array}$

กิ

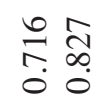

$\stackrel{n}{\stackrel{n}{8}}$

륭

我

$\begin{array}{ll}\infty & n \\ \infty & \infty \\ 0 & 0 \\ 0 & 0\end{array}$

ঙั?

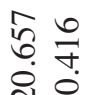

志

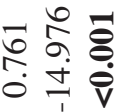

$\infty \frac{\infty}{\sim}$

กे ণิ จे

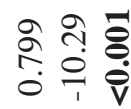

तิ

चे

$m$
$\infty$
0
$=$
$=$
$=$

กิ

๙2

๖ั

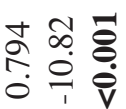

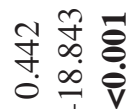

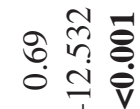

롱

ڤ్రి

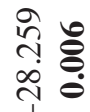

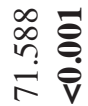

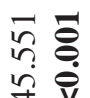

우훙

구용

के

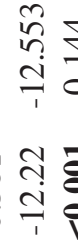

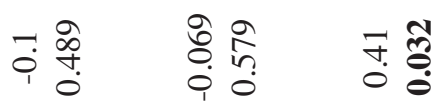

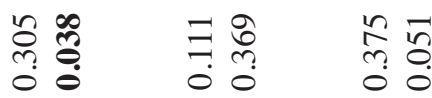

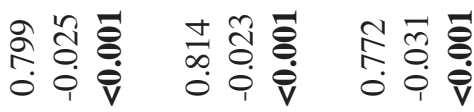

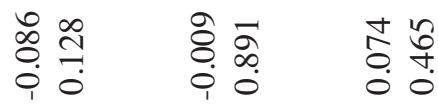

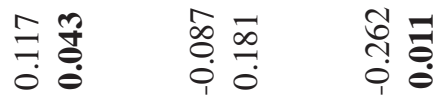

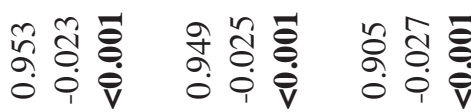

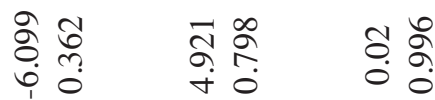

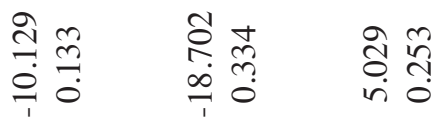

బิ

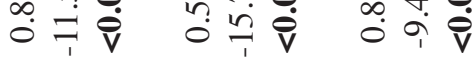

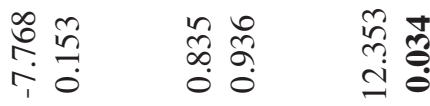

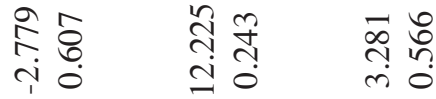

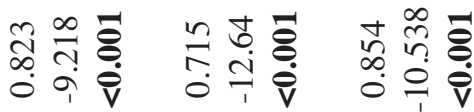

ते

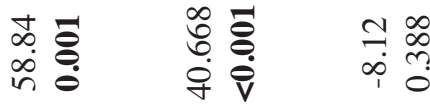

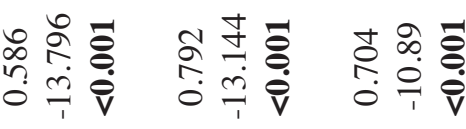

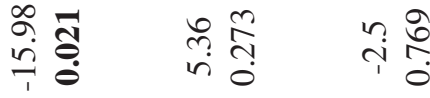

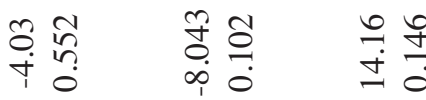

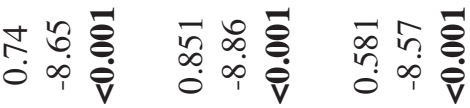

离 


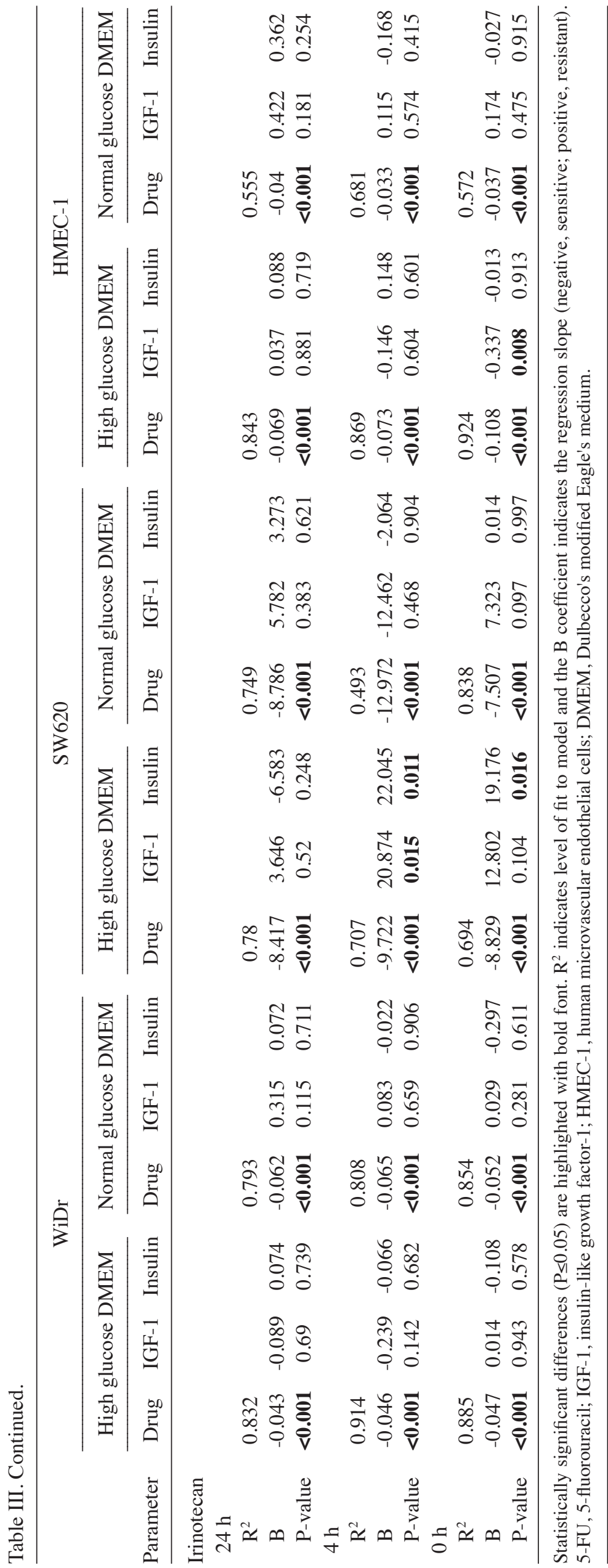




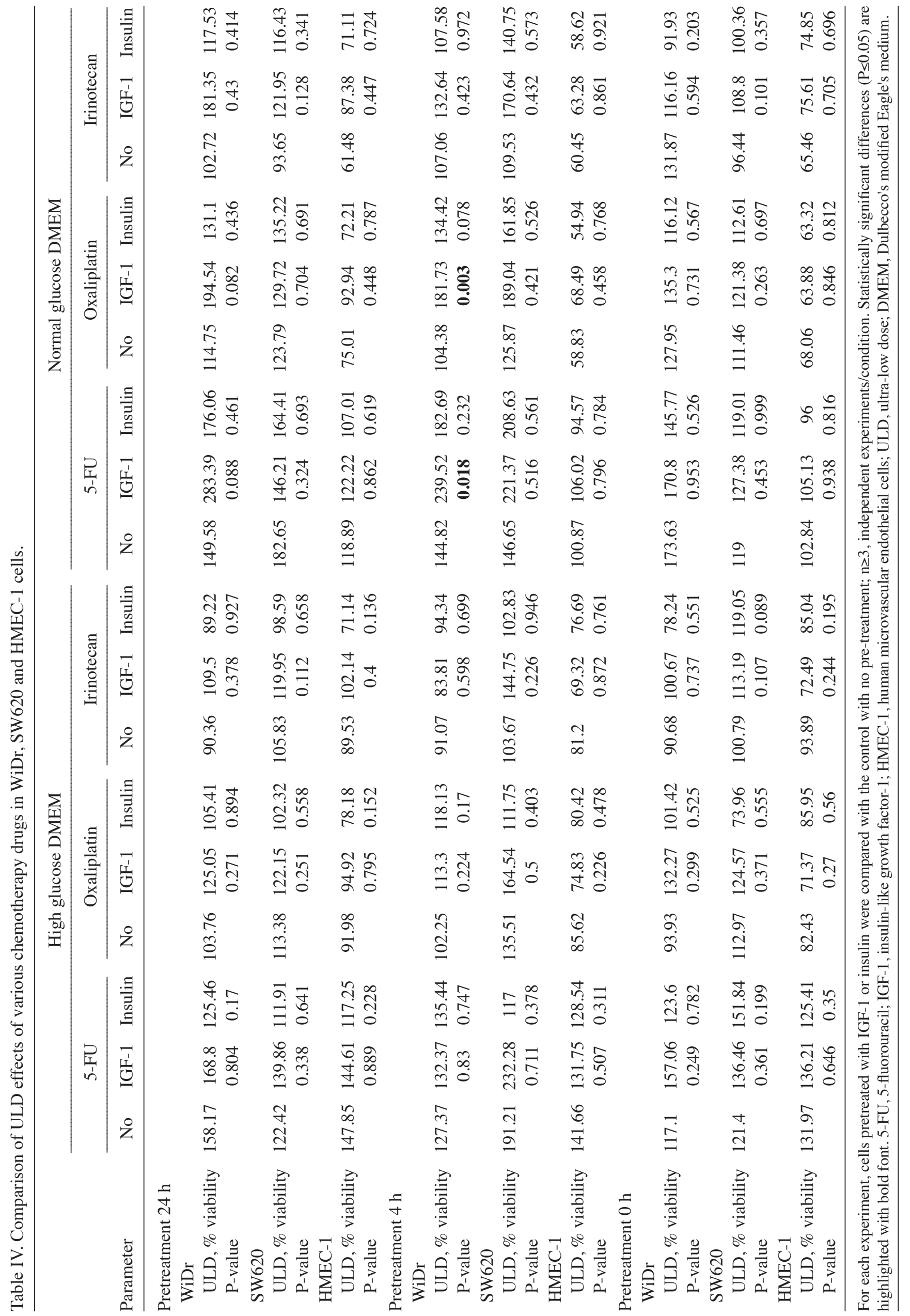


depends on and may be elucidated further using genetic and proteomic studies.

The results of the multivariable regression analysis from the current study are consistent with certain previously published studies, which have shown a chemosensitivity-promoting effect of insulin $(5,45,46)$ and IGF-1 $(47,48)$, although the effects varied with the cell line. Insulin is likely to act via growth promotion (49) and IGF-1 through the inhibition of apoptosis (50), via the phosphatidylinositol 3-kinase/Akt and mitogen-activated protein kinase/p38 signalling pathways (51).

Hypoxia has been shown to increase drug resistance (24), but the results of the present study show that HIF-1 is unlikely to be the main mechanism underlying IGF-1- and insulin-mediated drug response, as increases in HIF-1 levels were not associated with changes in the chemoresponse. However, the present results confirmed those of previous studies, which demonstrated that insulin, IGF-1 and high glucose levels regulate HIF-1 $\alpha(27,52)$.

The present study showed only a marginal impact of the prevailing glucose and insulin/IGF-1 environment on the chemotherapy response in colorectal cells in vitro, at clinically relevant 5-FU, oxaliplatin and irinotecan concentrations. However, there was evidence of a proliferative effect on WiDr cells at extremely low concentrations of 5-FU and oxaliplatin, alone or with IGF-1, as may occur in obesity. These in vitro results may have clinical implications in Western societies with increasing rates of obesity and colorectal cancer and the frequent under-dosing of obese cancer patients.

\section{Acknowledgements}

The authors would like to thank the funding agencies Genesis Oncology Trust (Bruce Blue Award, GUD) and the Tertiary Education Commission (Top Achiever Doctoral Scholarship, $\mathrm{EV}$ ) for their generous contributions.

\section{References}

1. Siegel R, DeSantis C, Virgo K, et al: Cancer treatment and survivorship statistics, 2012. CA Cancer J Clin 62: 220-241, 2012.

2. Lucas AS, O'Neil BH and Goldberg RM: A decade of advances in cytotoxic chemotherapy for metastatic colorectal cancer. Clin Colorectal Cancer 10: 238-244, 2011.

3. Dallas NA, Xia L, Fan F, et al: Chemoresistant colorectal cancer cells, the cancer stem cell phenotype, and increased sensitivity to insulin-like growth factor-I receptor inhibition. Cancer Res 69: 1951-1957, 2009.

4. Aschele C, Bergamo F and Lonardi S: Chemotherapy for operable and advanced colorectal cancer. Cancer Treat Rev 35: 509-516, 2009.

5. Zou K, Ju J and Xie H: Pretreatment with insulin enhances anticancer functions of 5-fluorouracil in human esophageal and colonic cancer cells. Acta Pharmacol Sin 28: 721-730, 2007.

6. Graham J, Muhsin M and Kirkpatrick P: Oxaliplatin. Nat Rev Drug Discov 3: 11-12, 2004.

7. Armand JP, Ducreux M, Mahjoubi M, et al: CPT-11 (Irinotecan) in the treatment of colorectal cancer. Eur J Cancer 31A: 1283-1287, 1995.

8. Calle EE, Rodriguez C, Walker-Thurmond K and Thun MJ: Overweight, obesity, and mortality from cancer in a prospectively studied cohort of U.S. adults. N Engl J Med 348: 1625-1638, 2003

9. Moghaddam AA, Woodward M and Huxley R: Obesity and risk of colorectal cacner: a meta-analysis of 31 studies with 70,000 events. Cancer Epidemiol Biomarkers Prev 16: 2533-2547, 2007.
10. Renehan AG, Tyson M, Egger M, Heller RF and Zwahlen M: Body-mass index and incidence of cancer: a systematic review and meta-analysis of prospective observational studies. Lancet 371: 569-578, 2008.

11. Campbell PT, Newton CC, Dehal AN, Jacobs EJ, Patel AV and Gapstur SM: Impact of body mass index on survival after colorectal cancer diagnosis: the Cancer Prevention Study-II Nutrition Cohort. J Clin Oncol 30: 42-52, 2012.

12. Simkens LH, Koopman M, Mol L, et al: Influence of body mass index on outcome in advanced colorectal cancer patients receiving chemotherapy with or without targeted therapy. Eur J Cancer 47: 2560-2567, 2011.

13. Meyerhardt JA, Niedzwiecki D, Hollis D, et al: Impact of body mass index and weight change after treatment on cancer recurrence and survival in patients with stage III colon cancer: findings from Cancer and Leukemia Group B 89803. J Clin Oncol 26: 4109-4115, 2008.

14. Griggs JJ and Sabel MS: Obesity and cancer treatment: weighing the evidence. J Clin Oncol 26: 4060-4062, 2008.

15. Litton JK, Gonzalez-Angulo AM, Warneke CL, et al: Relationship between obesity and pathologic response to neoadjuvant chemotherapy among women with operable breast cancer. J Clin Oncol 26: 4072-4077, 2008.

16. Pollak M: Insulin and insulin-like growth factor signalling in neoplasia. Nat Rev Cancer 8: 915-928, 2008.

17. Ahmed RL, Thomas W and Schmitz KH: Interactions between insulin, body fat, and insulin-like growth factor axis proteins. Cancer Epidemiol Biomarkers Prev 16: 593-597, 2007.

18. Biddinger SB and Kahn CR: From mice to men: insights into the insulin resistance syndromes. Annu Rev Physiol 68: 123-158, 2006.

19. Renehan AG, Frystyk J and Flyvbjerg A: Obesity and cancer risk: the role of the insulin-IGF axis. Trends Endocrinol Metab 17: 328-336, 2006.

20. Chen J, Katsifis A, Hu C and Huang XF: Insulin decreases therapeutic efficacy in colon cancer cell line HT29 via the activation of the PI3K/Akt pathway. Curr Drug Discov Technol 8: 119-125, 2011.

21. Adachi Y, Lee CT, Coffee K, et al: Effects of genetic blockade of the insulin-like growth factor receptor in human colon cancer cell lines. Gastroenterology 123: 1191-1204, 2002.

22. Gooch JL, Van Den Berg CL and Yee D: Insulin-like growth factor (IGF)-1 rescues breast cancer cells from chemotherapy-induced cell death - proliferative and anti-apoptotic effects Breast Cancer Res Treat 56: 1-10, 1999.

23. Perer ES, Madan AK, Shurin A, et al: Insulin-like growth factor I receptor antagonism augments response to chemoradiation therapy in colon cancer cells. J Surg Res 94: 1-5, 2000.

24. Roberts DL, Williams KJ, Cowen RL, et al: Contribution of HIF-1 and drug penetrance to oxaliplatin resistance in hypoxic colorectal cancer cells. Br J Cancer 101: 1290-1297, 2009.

25. Mole DR and Ratcliffe PJ: Cellular oxygen sensing in health and disease. Pediatr Nephrol 23: 681-694, 2008.

26. Fukuda R, Hirota K, Fan F, Jung YD, Ellis LM and Semenza GL: Insulin-like growth factor 1 induces hypoxia-inducible factor 1-mediated vascular endothelial growth factor expression, which is dependent on MAP kinase and phosphatidylinositol 3-kinase signaling in colon cancer cells. J Biol Chem 277: 38205-38211, 2002.

27. Doronzo G, Russo I, Mattiello L, Riganti C, Anfossi G and Trovati M: Insulin activates hypoxia-inducible factor-1alpha in human and rat vascular smooth muscle cells via phosphatidylinositol-3 kinase and mitogen-activated protein kinase pathways: impairment in insulin resistance owing to defects in insulin signalling. Diabetologia 49: 1049-1063, 2006.

28. Ades EW, Candal FJ, Swerlick RA, George VG, Summers S, Bosse DC and Lawley TJ: HMEC-1: establishment of an immortalized human microvascular endothelial cell line. J Invest Dermatol 99: 683-690, 1992.

29. Mosmann T: Rapid colorimetric assay for cellular growth and survival: application to proliferation and cytotoxicity assays. J Immunol Methods 65: 55-63, 1983.

30. Wang P, Henning SM and Heber D: Limitations of MTT and MTS-based assays for measurement of antiproliferative activity of green tea polyphenols. PLoS One 5: e10202, 2010.

31. Dachs GU, Steele AJ, Coralli C, et al: Anti-vascular agent Combretastatin A-4-P modulates hypoxia inducible factor- 1 and gene expression. BMC Cancer 6: 280, 2006.

32. American Diabetes Association: Diagnosis and classification of diabetes mellitus. Diabetes Care 35 (Suppl 1): S64-S71, 2012. 
33. Bartrons R and Caro J: Hypoxia, glucose metabolism and the Warburg's effect. J Bioenerg Biomembr 39: 223-229, 2007.

34. Costa A, Rios M, Casamitjana R, Gomis R and Conget I: High prevalence of abnormal glucose tolerance and metabolic disturbances in first degree relatives of NIDDM patients. A study in Catalonia, a mediterranean community. Diabetes Res Clin Pract 41: 191-196, 1998.

35. Kajantie E, Fall CH, Seppälä M, et al: Serum insulin-like growth factor (IGF)-I and IGF-binding protein-1 in elderly people: relationships with cardiovascular risk factors, body composition, size at birth, and childhood growth. J Clin Endocrinol Metab 88: 1059-1065, 2003.

36. Lahm H, Amstad P, Wyniger J, Yilmaz A, Fischer JR, Schreyer M and Givel JC: Blockade of the insulin-like growth-factor-I receptor inhibits growth of human colorectal cancer cells: evidence of a functional IGF-II-mediated autocrine loop. Int J Cancer 58: 452-459, 1994.

37. Bocci G, Danesi R, Di Paolo AD, et al: Comparative pharmacokinetic analysis of 5-fluorouracil and its major metabolite 5-fluoro-5,6-dihydrouracil after conventional and reduced test dose in cancer patients. Clin Cancer Res 6: 3032-3037, 2000.

38. Morrison JG, White P, McDougall S, et al: Validation of a highly sensitive ICP-MS method for the determination of platinum in biofluids: application to clinical pharmacokinetic studies with oxaliplatin. J Pharm Biomed Anal 24: 1-10, 2000.

39. Casale F, Canaparo R, Serpe L, Muntoni E, Pepa CD, Costa M, Mairone L, Zara GP, Fornari G and Eandi M: Plasma concentrations of 5-fluorouracil and its metabolites in colon cancer patients. Pharmacol Res 50: 173-179, 2004.

40. Kjellström J, Kjellén E and Johnsson A: In vitro radiosensitization by oxaliplatin and 5-fluorouracil in a human colon cancer cell line. Acta Oncol 44: 687-693, 2005.

41. Takimoto CH, Morrison G, Harold N, et al: Phase I and pharmacologic study of irinotecan administered as a 96-hour infusion weekly to adult cancer patients. J Clin Oncol 18: 659-667, 2000.

42. Tobin PJ, Beale P, Noney L, et al: A pilot study on the safety of combining chrysin, a non-absorbable inducer of UGT1A1, and irinotecan (CPT-11) to treat metastatic colorectal cancer. Cancer Chemother Pharmacol 57: 309-316, 2006.

43. Hunter RJ, Navo MA, Thaker PH, Bodurka DC, Wolf JK and Smith JA: Dosing chemotherapy in obese patients: actual versus assigned body surface area (BSA). Cancer Treat Rev 35: 69-78, 2009.
44. Chambers P, Daniels SH, Thompson LC and Stephens RJ: Chemotherapy dose reductions in obese patients with colorectal cancer. Ann Oncol 23: 748-753, 2012.

45. Ayre SG, Garcia y Bellon DP and Garcia DP Jr: Insulin, chemotherapy, and the mechanisms of malignancy: the design and the demise of cancer. Med Hypotheses 55: 330-334, 2000.

46. Damyanov C, Radoslavova M, Gavrilov V and Stoeva D: Low dose chemotherapy in combination with insulin for the treatment of advanced metastatic tumors. Preliminary experience. J BUON 14: 711-715, 2009.

47. Min Y, Adachi Y, Yamamoto $\mathrm{H}$, et al: Insulin-like growth factor I receptor blockade enhances chemotherapy and radiation responses and inhibits tumour growth in human gastric cancer xenografts. Gut 54: 591-600, 2005.

48. Warshamana-Greene GS, Litz J, Buchdunger E, Garcia-Echeverria C, Hofmann F and Krystal GW: The insulin-like growth factor-I receptor kinase inhibitor, NVP-ADW742, sensitizes small cell lung cancer cell lines to the effects of chemotherapy. Clin Cancer Res 11: 1563-1571, 2005.

49. Desbois-Mouthon C, Cadoret A, Blivet-Van Eggelpoël MJ, et al: Insulin-mediated cell proliferation and survival involve inhibition of c-Jun $\mathrm{N}$-terminal kinases through a phosphatidylinositol 3-kinase- and mitogen-activated protein kinase phosphatase-1-dependent pathway. Endocrinology 141: 922-931, 2000.

50. Hopkins A, Crowe PJ and Yang JL: Effect of type 1 insulin-like growth factor receptor targeted therapy on chemotherapy in human cancer and the mechanisms involved. J Cancer Res Clin Oncol 136: 639-650, 2010.

51. Sung MK, Yeon JY, Park SY, Park JH and Choi MS: Obesity-induced metabolic stresses in breast and colon cancer. Ann NY Acad Sci 1229: 61-68, 2011.

52. Scharte M, Jurk K, Kehrel B, Zarbock A, Van Aken H and Singbartl K: IL-4 enhances hypoxia induced HIF-1alpha protein levels in human transformed intestinal cells. FEBS Lett 580: 6399-6404, 2006.

53. Ikediobi ON, Davies H, Bignell G, et al: Mutation analysis of 24 known cancer genes in the NCI-60 cell line set. Mol Cancer Ther 5: 2606-2612, 2006.

54. Spitzner M, Emons G, Kramer F, et al: A gene expression signature for chemoradiosensitivity of colorectal cancer cells. Int J Radiat Oncol Biol Phys 78: 1184-1192, 2010. 